\title{
Comparison of the intake and digestibility of different diets in llamas and sheep: a preliminary study
}

\author{
JP Dulphy, C Dardillat, M Jailler, JP Jouany \\ INRA, Station de Recherches sur la Nutrition des Herbivores, Theix, \\ F 63122 Saint-Genès-Champanelle, France
}

(Received 8 June 1993; accepted 28 December 1993)

\begin{abstract}
Summary - Three diets (hay, straw with soya cake with or without barley) were fed to 3 llamas and 3 sheep. The 2 species ingested the same quantity of hay, but llamas ingested $14 \%$ more straw (in $\mathrm{g} / \mathrm{kg}$ LW). OM digestibility of straw was higher in llamas (+ 3.8 points). Mean retention time of DM was higher in llamas ( $32 \mathrm{~h}$ against $25 \mathrm{~h}$ for sheep). Reticulo rumen $\mathrm{pH}$ was more stable in llamas and also higher than in sheep. In conclusion the ability of llamas to use low quality roughage seems to be more efficient than that of sheep.
\end{abstract}

intake / digestibility / roughage / sheep / llama

Résumé - Comparaison de l'ingestibilité et de la digestibilité d'un foin et d'une paille par des lamas et des moutons. Étude préliminaire. Les quantités de MS ingérées de 3 rations (un foin, une paille + tourteau de soja sans ou avec orge) et la digestibilité des 2 rations à base de paille ont été comparées chez des lamas et des moutons munis de fistules du rumen. Des mesures complémentaires ont été faites pour caractériser les conditions de la digestion des rations étudiées dans les réservoirs prégastriques. Par rapport à leur poids vif, lamas et moutons ont ingéré la même quantité de foin $(17,4 \mathrm{~g} / \mathrm{kg} P V)$, mais les lamas ont ingéré $14 \%$ de paille en plus $(13,2 \mathrm{~g}$ vs $11,6 \mathrm{~g} / \mathrm{kg} P V)$. L'apport d'orge n'a eu aucun effet sur les quantités de paille ingérées. La digestibilité de la MO de la paille a été supérieure de 3,8 points chez les lamas (+ 4,4 points pour les parois végétales). Après le repas principal du matin, et rapportée au poids vif des animaux, la quantité de contenu frais des compartiments 1 et 2 des lamas a été très légèrement plus élevée de $5 \%$ que celle du réticulo-rumen des moutons, mais supérieure de $34 \%$ avant (respectivement +6 et $+42 \%$ pour les contenus secs). Dans ces conditions le temps de séjour moyen de la MS dans ces réservoirs gastriques a été de 32 h chez les lamas vs 25 chez les moutons. Le pH des contenus stomacaux est beaucoup plus stable et plus élevé chez les lamas que chez les moutons. Cet essai confirme la bonne aptitude des lamas à utiliser des fourrages pauvres et apporte quelques éléments d'explication. Des études plus approfondies sont cependant nécessaires. 


\section{INTRODUCTION}

The nutritional value of a forage for ruminants is determined by 2 factors, intake and digestibility. Very few comparative studies of nutritional value of forage have been performed in llamas and sheep. Three reports concern intake: one by Warmington et al (1989) with rye-grass straw; one by Cordesse et al (1992) with lucerne hay and ammonia-treated straw; and one by Dulphy et al (1994) with hay. For these 4 forages the overall intake in llamas was $16 \mathrm{~g}$ dry matter (DM)/kg live weight (LW), compared with $21 \mathrm{~g}$ in sheep, ie 49 and $59 \mathrm{~g} / \mathrm{kg}$ body weight (W) 0.75 respectively. Three reports concern digestibility: Hintz et al (1973), and above-cited works of Warmington et al (1989) and Cordesse et al (1992). The average organic matter (OM) digestibility of the 5 forages studied was $64.3 \%$ in the llamas and $61.0 \%$ in sheep.

Because of their uncommon physiological characteristics (Engelhardt and Höller, 1982) there is growing interest in the study of camelids. However, little has been published on quantitative aspects. It was therefore decided to perform a trial comparing 3 diets, distributed simultaneously to llamas and sheep. This trial was a continuation of the studies performed by Kayouli et al (1993a) and Dardillat et al (1994) on the ruminal conditions in llamas, which are more efficient in digesting plant cell walls than sheep.

\section{MATERIALS AND METHODS}

\begin{abstract}
Animals
Three llamas and 3 sheep were used. The animals were 4-year-old castrated males. The average LW of llamas, $98 \mathrm{~kg}(90-106 \mathrm{~kg})$, was higher than that of sheep, $71 \mathrm{~kg}(69-74 \mathrm{~kg})$. All animals had been fitted with a rumen fistula with a diameter of 90 and $75 \mathrm{~mm}$, respectively, since the age of 2 years.
\end{abstract}

\section{Feed}

Three diets were studied: $A$ - hay from natural grassland; B - wheat straw with addition of $150 \mathrm{~g}$ soya cake (SC) and $20 \mathrm{~g}$ mineral mixture; and $\mathrm{C}$ - the same straw and same supplements with $350 \mathrm{~g}$ of ground and pelleted barley. Table I shows the characteristics of the diets.

\section{Experimental design}

The experimental design for each species was a latin square: 3 diets, 3 animals, 3 periods of 5 weeks each. The forages were distributed in a single meal, with refusal being fixed at approximately $20 \%$ of the daily intake. The forage was distributed at $9 \mathrm{am}, 30 \mathrm{~min}$ after the distribution of the feed supplements (SC, minerals and barley). The trial took place from October to December 1992, and the animals were in 2 climatised rooms. Two llamas developed digestive troubles after 3 weeks. These troubles occurred after the main measurements and had few repercussions, but it was impossible to record feed intake behaviour of the 2 sick animals.

Table I. Characteristics of the feed used .

\begin{tabular}{lrrrr}
\hline & Hay & Straw & Soya cake & Barley \\
\hline DM content $(\mathrm{g} / \mathrm{kg})$ & 886 & 889 & & \\
Ash $(\mathrm{g} / \mathrm{kg} \mathrm{DM})$ & 77 & 120 & 795 & 896 \\
Crude protein a $(\mathrm{g} / \mathrm{kg} \mathrm{DM})$ & 94 & 58 & 518 & 58 \\
Cell-wall constituents $(\mathrm{g} / \mathrm{kg} \mathrm{DM})$ & 706 & 769 & 115 & 115 \\
& & & & \\
\hline
\end{tabular}

a Crude protein: $\mathrm{N} \times 6.25$. 


\section{Measurements}

The forage offered and refused was weighed daily. The digestibilities of diets $B$ and $C$ were determined from total faeces collected in metabolism crates over a period of $6 \mathrm{~d}$ in the third week of each period.

During the next 1 -week period, the reticulorumen of the sheep and compartments 1 and 2 of the llamas were manually emptied twice, once before diet distribution and once $\mathbf{1 5 0} \mathrm{min}$ after distribution. The digesta were weighed, sampled and returned to the stomach. A 3-day interval was respected between the both emptyings.

In addition, water intake (for a total of $17 \mathrm{~d}$ per animal per period) and the feed intake activities of the llamas ( $3 \mathrm{~d}$ per animal per period) were recorded (Ruckebusch, 1963). This was not done for sheep.

\section{Chemical analyses and statistical calculations}

The methods used for the analyses of dietary and digestive content components have been described previously (Chiofalo et al, 1992). Standard deviation and comparisons between means were calculated with the SAS package (1985). For each parameter (except digestibility) a total of 18 results was used. The effect of period ( $2 d f$, and that of individuals $(5 d f)$ were determined to keep that of species $(1 d t)$. A possible effect of experimental room was included in the error term of the model used.

\section{RESULTS}

\section{DM intake}

There were no refusals for soya cake, minerals and barley supplements. The period of measurement had no effect on intake level. Under these conditions, llamas and sheep had the same hay intake in relation to their $L W$ but the llamas ingested $14 \%$ more straw. Addition of barley had no effect on straw intake (table II).
Because of the tolerated level of refusal, the animals could be slightly selective in their intake. Surprisingly, llamas seemed to be more selective when offered hay, whereas sheep had a greater selectivity for straw (see table II), for the composition of refusals).

\section{Digestibility}

On average, llamas digested straw more efficiently (+ 3.8 units) particularly when no barley was added $(+5.0)$. If the ability of the 2 species to digest the supplements is equal, then the presence of barley seemed to reduce the efficiency of llamas in digesting straw, which remains higher in this species. The digestibility of straw cell walls was 4.4 units higher in llamas and 5.7 units higher when there was no barley in the diet. The non-digestible nitrogen content was greater in the llamas (+ $3.5 \mathrm{~g}$ per $\mathrm{kg}$ ingested DM).

\section{Characteristics of reticulo-ruminal contents}

The digesta contents of the fermentative compartments (compartments 1 and 2 for llamas and the reticulo-rumen for sheep) are given in table III, together with the amount of DM ingested the day before the fermentation compartments were emptied.

Before the main meal, the quantity of fresh and dry content accounted for respectively $16.5 \%$ and $1.8 \%$ of the $L W$ in llamas and 12.3 and $1.3 \%$ in sheep, ie +34 and $+42 \%$ in llamas. After the main meal the respective values were 19.1 and $2.4 \%$ in llamas and 18.2 and $2.2 \%$ in sheep, ie +5 and $+6 \%$ in llamas. If the average amount of content is considered to be close to the half-total of the values observed before and after the main meal, it is possible to calculate the mean residence time of digesta in the 
Comparisons between llamas and sheep

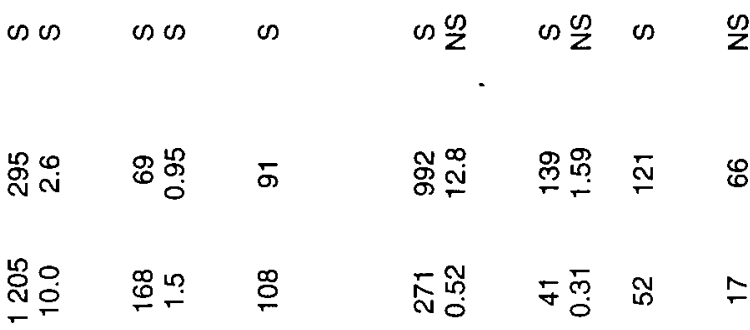

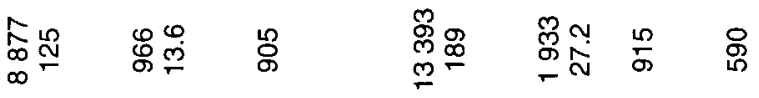

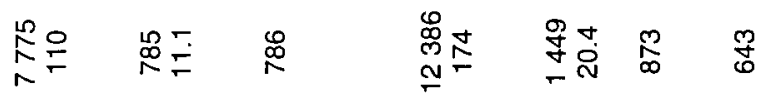

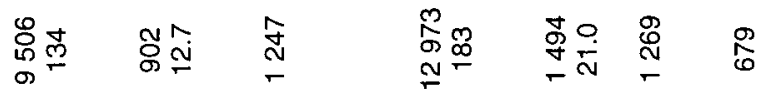

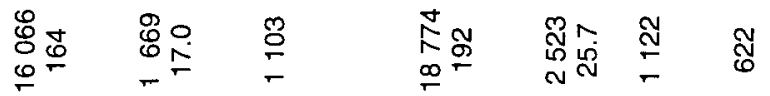

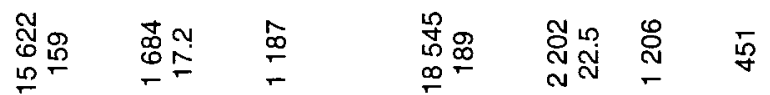

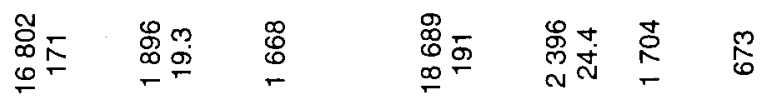

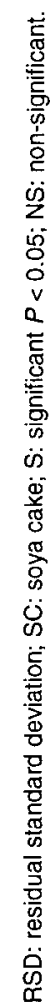


reticulo-rumen. This time was $32 \mathrm{~h}$ in llamas and $25 \mathrm{~h}$ in sheep; the corresponding turnover rates for DM were 3.07 and $3.95 \% / h$ for llamas and sheep respectively (table IV). For cell walls, the mean residence times in the rumen were 36 and $28 \mathrm{~h}$, with turnover rates of 2.78 and $3.67 \% / \mathrm{h}$ in llamas and sheep, respectively.

The increased retention time in llamas, by comparison to sheep, was accompanied by a higher proportion of the cell walls in the digesta both before the meal (735 vs $712 \mathrm{~g} / \mathrm{kg} \mathrm{DM}$ ) and after it (735 vs $700 \mathrm{~g} / \mathrm{kg}$ DM) (table V). In llamas, the $\mathrm{pH}$ of digesta was 7.11 and 7.07 before and after the main meal. These values were higher and more stable than in sheep (6.78 and 6.56) (table V). In addition, the ammonia nitrogen content after the main meal was higher in sheep, probably because they had a greater proportion of soya cake than llamas in the diets.

It is also interesting to note that the DM content of the rumen digesta was increased in llamas when they received the hay diet
(120 for llamas vs $104 \mathrm{~g} \mathrm{DM} / \mathrm{kg}$ of content for sheep). This increase was accompanied by a slightly higher osmotic presure in llamas (287 vs $268 \mathrm{~m}$ osm $/ \mathrm{ml}$ ).

For the straw diets, there was a significant difference between the 2 species in the distribution of particles according to their size. The amounts of fecal particles $\geq 1 \mathrm{~mm}$ found per $100 \mathrm{~g}$ of fecal DM were $3.4 \mathrm{~g}$ in the llamas and $1.5 \mathrm{~g}$ in the sheep.

\section{DISCUSSION}

Although the number of animals used in this preliminary trial was rather small, the first findings of this comparative study include various interesting points, especially because the literature concerning this subject is scarce.

In relation to their $L W$, the llamas had a DM intake comparable to that of sheep, as previously observed by Warmington et al (1989). The results of Cordesse et al (1992), who reported lower DM intake for llamas,

Table IV. Turnover rate of reticulo-rumen contents.

\begin{tabular}{|c|c|c|c|c|c|c|}
\hline & \multicolumn{3}{|c|}{ Diets for llamas } & \multicolumn{3}{|c|}{ Diets for sheep } \\
\hline & Hay & Straw & $\begin{array}{l}\text { Straw + SC } \\
+ \text { barley }\end{array}$ & Hay & Straw & $\begin{array}{c}\text { Straw + SC } \\
+ \text { barley }\end{array}$ \\
\hline \multicolumn{7}{|l|}{ Dry matter } \\
\hline Total intake $(\mathrm{g})$ & 1686 & 1331 & 1562 & 1258 & 965 & 1360 \\
\hline Mean content $(\mathrm{g})$ & 2146 & 1943 & 2096 & 1198 & 1117 & 1450 \\
\hline Turnover rate/h (\%) & 3.27 & 2.85 & 3.10 & 4.34 & 3.60 & 3.91 \\
\hline Mean retention time (h) & 30 & 35 & 32 & 23 & 28 & 26 \\
\hline \multicolumn{7}{|l|}{ Cell walls (NDF) } \\
\hline Total intake $(\mathrm{g})$ & 1190 & 935 & 923 & 888 & 654 & 773 \\
\hline Mean content $(\mathrm{g})$ & 1606 & 1436 & 1503 & 880 & 780 & 980 \\
\hline Turnover rate/h (\%) & 3.08 & 2.71 & 2.56 & 4.20 & 3.49 & 3.29 \\
\hline Mean retention time $(h)$ & 32 & 37 & 39 & 24 & 29 & 30 \\
\hline
\end{tabular}

SC : soya cake. NDF: neutral detergent fiber. 


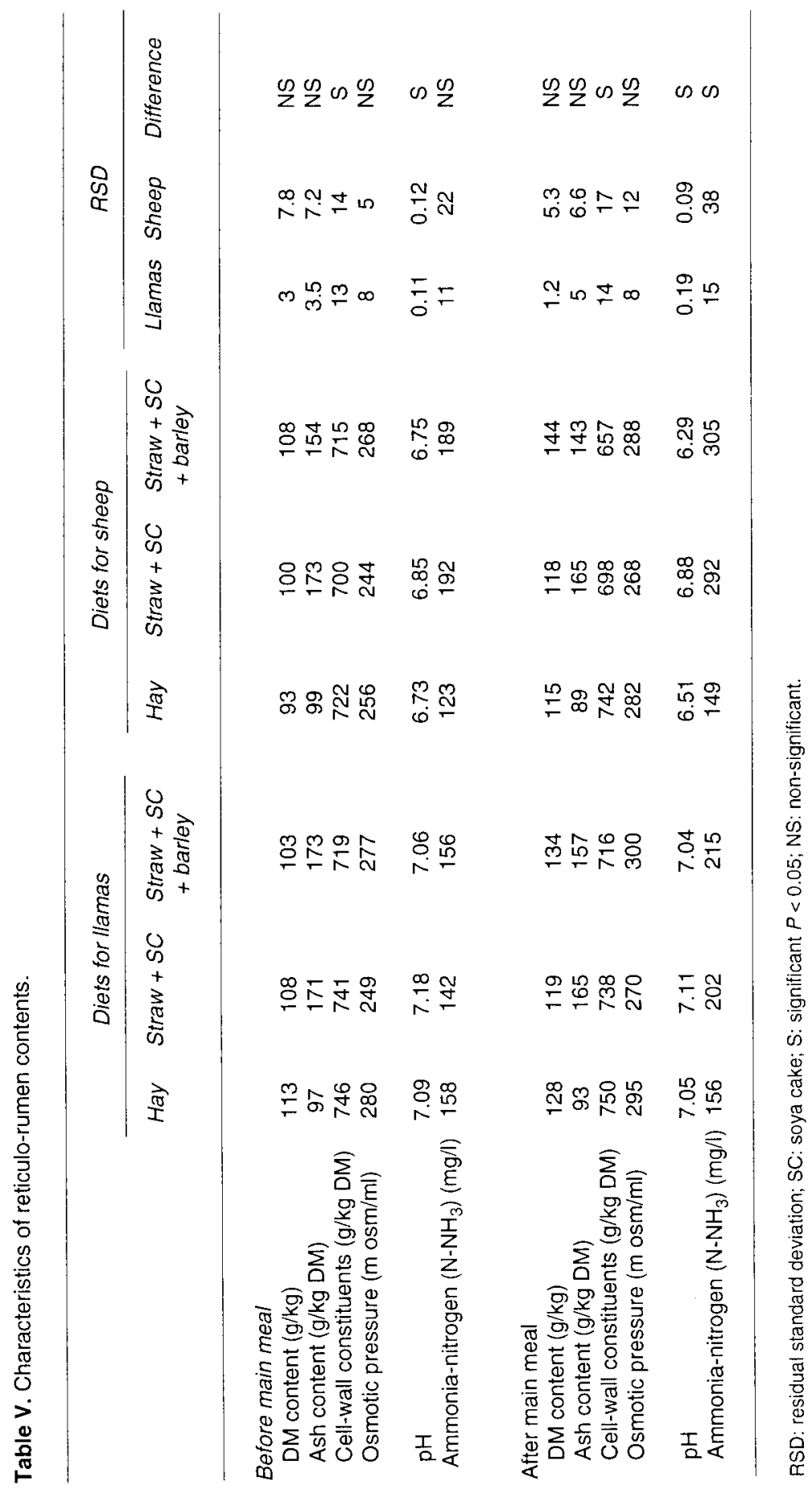


were obtained with specific forages that possibly were unpalatable to these animals because of the high nitrogen content (as observed in another camelid, the dromedary). Further studies are therefore needed to have reliable comparative data between animals. Neither sheep nor llamas modified their straw intake when concentrates were added to the diet. The same observation was made in sheep when concentrates were limited $30 \%$ of total DM intake (Dulphy et al, 1983).

In terms of diet digestibility, however, llamas seem to be more efficient than sheep, which is consistent with other published results. It remains to be confirmed if this increased efficiency persists when starch is added to the diet. The observation is surprising, however, since it has been shown that llamas can regulate the $\mathrm{pH}$ of their forestomach content very efficiently (Dardillat et al, 1994). It is likely that this negative effect comes from the starch itself since it was observed in both animal species.

We have no direct comparisons between water intake in llamas and sheep. Data obtained from llamas were on average $2.87 \mathrm{l} / \mathrm{kg}$ DM intake. They were higher than the value of $2.1 \mathrm{l} / \mathrm{kg}$ DM reported by Warmington et al (1989). There are no published observations on the comparison of intake behaviour of llamas and sheep. We observed an ingestion time of $335 \mathrm{~min} / \mathrm{d}$ and rumination time of $520 \mathrm{~min} / \mathrm{d}$ for llamas fed hay and straw. The values for hay and straw were nearly identical. A striking observation is the low frequency of rumination periods, $6.3 / \mathrm{d}$, and thus the extended length of each period. Therefore a comparative study involving sheep would be novel and of interest.

In relation to their live weight or their intake, llamas had greater digesta content than sheep in their 2 first forestomachs. Dardillat et al (1994) obtained a comparable result in relation to the DM intake. Under these conditions, there is probably an increased retention time of DM, which would largely explain the greater digestibility of straw in llamas. This higher ability to digest straw was previously observed by Kayouli et al (1993b) in dromedaries. This difference in digestibility could also be eyplained by greater cellulolytic activity of the ruminal microbes in llamas (Kayouli et al, 1993a). However, further studies are required in which the 2 mechanisms will be investigated simultaneously.

In this study, the maximum capacity of the 2 forestomachs were comparable for both species. The main physico-chemical difference was a higher $\mathrm{pH}$ in llamas, a finding that contradicts the results of Vallenas and Stevens (1971), but is consistent with the observation that llamas buffer their stomach contents better than sheep (Dardillat et al, 1994). Osmotic pressure was always higher in llamas, particularly those fed diets with hay and straw with barley. At $\mathrm{pH} 7$, buffers must be important to neutralise volatile fatty acids, which are in an ionic form near neutrality. These 2 factors can explain the higher osmotic pressure.

Similar to results reported by Warmington et al (1989), a higher proportion of large particles were found in the faeces of llamas than in those of sheep. However, in relation to the DM excreted in the faeces, the amount found really excreted per day was not different, which is further evidence that llamas, like other small ruminants, are efficient in reducing feed into small particles.

Although further studies are needed, the ability of llamas to use low-quality roughage, observed by Warmington et al (1989), was confirmed by this study. A more comprehensive understanding of digestive and physiological mechanisms involved would be of help in research on how to improve the use of roughage by all ruminants. 


\section{REFERENCES}

Chiofalo V, Dulphy JP, Baumont R (1992) Influence of the method of forage conservation on feeding behaviour, intake and characteristics of reticulorumen content, in sheep fed ad libitum. Reprod Nutr Develop 32, 377-392

Cordesse R, Inesta M, Gaubert JL (1992) Intake and digestibility of four forages by llamas and sheep. Ann Zootech 41, 91-92

Dardillat C, Baumont R, Jouany JP (1994) Contenus gastriques du lama et du mouton. Ann Zootech 43 , 279

Dulphy JP, Breton J, Louyot JM, Bienaimé A (1983) Étude de la valeur alimentaire des pailles de céréales traitées ou non à la soude. III. Influence du niveau d'apport d'aliment concentré. Ann Zootech 32, 53-80

Dulphy JP, Jouany JP, Martin-Rosset W, Theriez M (1994) Aptitudes comparées de différentes espèces d'herbivores domestiques à ingérer et digérer des fourrages distribués à l'auge. Ann Zootech 43, 11-32

Engelhardt WV, Höller H (1982) Salivary and gastric physiology of camelids. Verh Disch Zool Ges 195204
Hintz HF, Schryver HF, Halbert M (1973) A note on the comparison of digestion by New World camels, sheep and ponies. Anim Prod 16, 303-305

Kayouli C, Dardillat C, Jouany JP (1993a) Comparative study of the muralytic activity of rumen microbes measured in situ in llamas and sheep. Ann Zootech 42,184

Kayouli C, Jouany JP, Demeyer DI, Ali-Ali, Taoueb H, Dardillat C (1993b) Comparative studies on the degradation and mean retention time of solid and liquid phases in the forestomachs of dromedaries and sheep fed on low-quality roughages from Tunisia. Anim Feed Sci Technol 40, 343-355

Ruckebusch Y (1963) Recherches sur la régulation centrale du comportement alimentaire chez les ruminants. Thèse Universitè de Lyon, $213 p$

SAS Institute (1985) SAS Users'guide. SAS Institute Inc, USA

Vallenas A, Stevens CE (1971) Volatile fatty acid concentrations and $\mathrm{pH}$ of llama and guanaco forestomach digesta. Cornell Vet 61, 239-252

Warmington BG, Wilson GF, Barry TN (1989) Voluntary intake and digestion of rye-grass straw by llama $x$ guanaco crossbreds and sheep. J Agric Sci Camb $113,87-91$ 